\title{
Filial Phantasmagoria
}

\section{The Apocryphal Sons of Antonio Maceo (Father of the Cuban Nation)}

\author{
Jennifer L. Lambe \\ Brown University \\ jennifer_lambe@brown.edu
}

\begin{abstract}
Antonio Maceo Grajales $\left(1845^{-1896)}\right.$ is one of the most celebrated heroes of Cuban independence. Though he died before he could see the dawn of a sovereign, if U.S.occupied, Cuba, Maceo would become an important node of nationalist commemoration. Throughout this process, Maceo's blackness represented both a source of his prestige - the struggle against African slavery had been intimately tied to independence - and a barometer of lingering racial inequalities. Posthumous depictions thus tended to downplay racial tensions in a unifying vision of nation. Yet Maceo's martyrdom in the Spanish-Cuban-American War also reverberated in more uncanny registers. Before and after his death, apocryphal sons emerged periodically from the shadows, opening battles over Maceo's legacy. In their movement across borders, these real and apocryphal children gave voice to silences around race and sovereignty as they converged on the body of their lionized "father," while also opening up narrative spaces wherein the status quo could be reimagined.
\end{abstract}

\section{Keywords}

Antonio Maceo - Cuba - U.S. imperialism - race - sovereignty - historical memory

Reporting from Madrid's Teatro de la Comedia several years after Cuba's final battle for independence (1895-98), a Spanish correspondent found himself in the company of Panchito Maceo Fernández, a self-proclaimed son of the island's liberator, Antonio Maceo. Maceo, along with José Martí, was one of the symbolic fathers of the Cuban nation; like Martí, he had sacrificed his life in pursuit of freedom from Spain. The journalist was thus bemused to encounter a humble doorman claiming Maceo's illustrious heritage:

(C) JENNIFER L. LAMBE, 2019 | DOI:10.1163/22134360-09301051

This is an open access article distributed under the terms of the prevailing CC-BY-NC license 
I looked at my interlocutor ... and I saw that, in effect, like Maceo himself, there was no sign in his face, aside from its color, of the characteristic irregularities of his race.

His nose is narrow. His lips aren't monstrous.

Journalist: How did you end up in Spain?

Panchito: With the battalion of the Cazadores de Barcelona [a volunteer regiment sent from Catalunya to fight in the Cuban independence struggle].

Journalist: And now, just as your father was a hunter of men in the war, you're a hunter of women on Príncipe Street?

Panchito: Yes, sir; but who knows what Destiny holds for me! ... My father, at my age, delivered supplies on muleback.

The "chasseur de la Comedia," the reporter opined, was decidedly a "joker in poor taste."

Struggles for sovereignty invariably produce orphans: countries without pasts, children without fathers. These fatherless sons and daughters bear the weight of inventing tradition, of combing through the carnage in search of usable pasts. Such scripting demands that its authors find among the objects of their grief a path to less mournful futures. And so human fathers became immortal heroes, idealized avatars of tentative nations.

The Cuban struggle for independence from Spain was both tragic and transcendent. Over the course of three separate conflicts - the Ten Years' War (1868-78), the "Little War" (1879-80), and the Spanish-Cuban-American War (1895-98) — a battle for national sovereignty morphed into something more radical: a challenge to the social order, born of slavery and white supremacy. In a society still in the throes of African slavery, this commitment to racial inclusion represented a catalytic force within the evolving construction of nation, but it was also a source of friction within the insurgent ranks. Spain stoked the fears of white Cubans by casting the independence struggle as a "race war," and many within the pro-independence faction willingly accepted that association. Yet the final demise of slavery by 1886 only reinforced the link between national independence and racial justice. Cubans of African descent served as a vanguard in advancing this more profound articulation of anticolonial dissent (Cepero Bonilla 1948; Ferrer 1999; Scott 1985).

1 “Crónica interesante," La Lucha, November 21, 19o9, 12. 
One black general in particular would come to embody the reciprocal construction of an antiracist and anti-imperial future for the island. Antonio Maceo Grajales was born in 1845 to a modest farming family in eastern Cuba. As a young man, he, along with his father and brothers, joined the independence struggle only weeks after it began; many of them would also sacrifice their lives to the cause. A brave and brilliant soldier, Maceo rose quickly within the insurgent ranks. When a majority of white Cubans prepared to surrender to Spain in 1878, Maceo dramatically fought on, refusing to accept a peace in which slavery and colonialism persisted. The resulting "Little War" soon ended in defeat, and Maceo departed Cuba into a decade of exile in Jamaica, Haiti, Costa Rica, Honduras, and the United States. He would return to the island for the final stage of the war and lead a westward invasion of Cuba, piercing the historic heart of colonial power. In 1896, his forces were ambushed and Maceo, who had come to be known as the "Bronze Titan" by his troops, was killed. ${ }^{2}$

There are two recognized fathers of the Cuban nation who have often served as foils for each other: José Martí (1853-95), a white writer commonly portrayed as the ideological author of independence, and Maceo, more often cast as the military agent of its construction. Neither survived to see the dawn of a free nation in Cuba, yet both would become an integral part of its fabric. Enshrined in the state's secular religion, Martí and Maceo would enter a nationalist afterlife as the pillars of sovereign promise, even when the Cuban republic failed to live up to that ideal.

Yet the mourning of martyrs did not always translate straightforwardly into national apotheosis. Rather, the losses bound up in the independence struggle would resurface in an uncanny phenomenon: a posthumous fixation on Maceo's paternity. Beginning before and continuing for several decades after his death, Maceo began to spawn apocryphal children, both within and beyond Cuba. Their claims on his lineage would provoke newspaper coverage throughout the Americas and debates within Cuba, where his partisans worked to discredit such claims as discretely as possible. Such debates over the descent of the island's liberators were a broader phenomenon of the postindependence era, ${ }^{3}$ though others were perhaps more prodigious in producing (extramari-

2 José Luciano Franco's multivolume biography of Maceo (published 1951-57) has long been the standard reference work, and it was joined by many accounts published around the centenary of Maceo's birth by a new generation of Maceo scholars, including Olga Portuondo Zúñiga and Rafael Duharte Jiménez. For a representative sample of this new scholarly literature, which has also centered other members of Maceo's family, see Escalona Chádez \& Torres Elers 2016. I am grateful to an anonymous reader for suggesting this source.

3 Cubans have long speculated that José Martí fathered a daughter, María Mantilla, with Car- 
tal) offspring. ${ }^{4}$ In fact, Maceo had only one recognized son, Antonio Maceo Maryatt, born in 1881 to Maceo's lover, Amelia Maryatt, during his Jamaican exile; his marriage to Maria Cabrales produced no surviving offspring. ${ }^{5}$ In their place, we instead find these (allegedly) counterfeit children, who jostled for recognition in the public eye.

Maceo's false sons dramatically incarnate Cuba's halting transition to nationhood after 1898. Through a last-minute intervention in the war against Spain, the United States inexorably insinuated itself in Cuba's future. U.S. politicians, corporations, and cultural institutions, especially the media, would thereafter play an outsized role in shaping the political and social life of the island (Pérez 1999). Yet the imperial center and its frontier also became, for elite and ordinary islanders alike, a space for imaginative self-making-hospitable territory for chameleons. The broader Caribbean was also part of this borderlands world, in which the imperial reach of the United States was refracted in anti-colonial imaginaries stretching from Jamaica to Central America. Unsurprisingly, the United States and its press outlets would also provide a stage for Maceo's (un)recognized offspring.

Transnational wanderings thus enabled mobility and reinvention. Race, on the other hand, represented more complicated baggage. Maceo's sons moved back and forth between a new nation that claimed "racelessness" - the renunciation of race as a dividing line among Cubans, whatever the inconsistencies in practice - and an imperial power that grounded both its external and internal logics of domination in racial hierarchy, most notoriously Jim Crow segregation

men Miyares while in exile in New York, though Martí always denied the charge. Martís relationship with Miyares does not appear to have raised eyebrows until the death of Miyares's husband in 1885, and María did not identify as Martís daughter until much later. But her son, actor César Romero, would present himself as Marti's grandson throughout his life, and María would ultimately seek official recognition from Fulgencio Batista as four of her grandchildren would do with Fidel Castro, to no avail. See Carlos A. Rodríguez Martínez, "Nadie tiene que juzgar a Martí," Vanguardia, May 21, 2016, http://www.vanguardia.cu/de-cuba/6278 -nadie-tiene-que-juzgar-a-marti, accessed December 12, 2018; and Yamil Díaz Gómez, "Martí y María Mantilla: ¿qué dice la ciencia?," Cubadebate, January 24, 2012, http://www.cubadebate .cu/noticias/2012/o1/24/marti-y-maria-mantilla-lo-que-dice-la-ciencia/\#.WOZf8VPytUN, accessed December 12, 2018.

4 Máximo Gómez, the Dominican-born leader of Cuba's independence army, was particularly notorious on this score. I am grateful to Marial Iglesias Utset for alerting me to the prevalence of individuals claiming to be descendants of Gómez in the early twentieth century. On the familial contours of the independence struggle, see Álvarez Pitaluga 2008 and Mirabal 2013.

5 Cuban observers have long posited that a young boy and girl born to Cabrales died during the war, but no existing documentation confirms their birth or death. On this debate, see Torres Elers (2013:59-66) and Sosa Borjas (2015:161-64). 
(de la Fuente 2001; Guridy 2010; Luis-Brown 2010). Yet ordinary people found room, however limited, to negotiate these constraints. Passing was a key subaltern strategy for accommodating racialized power structures (Hobbs 2016; Jacoby 2016; Morrison 2015).

Here, I follow the efforts of three unrecognized sons (Santiago, Daniel, and Gregorio) and one official son (Antonio) to navigate the racial, social, and political borders they crossed. The stories told about these young men, who received the most attention within a crowded field of aspiring offspring, highlight the stakes attached to Cuba's nationalist family saga, along with its buried fault lines. In the early twentieth century, nation building was framed as a patrilineal process, centered on the martyred patriarchs whose aura sanctified sovereignty. Both Cuban nationalists and U.S. imperialists mobilized familial discourses to make their claims on Cuba's future. The familiarization of political culture tended to obscure the silences on which the nation had been built, from imperial oversight to racial inequity.

Race connects the political to the filial, both discursively and genealogically. To honor the broad mobilization that had overturned Spanish colonialism, Cubans were encouraged to rise above their racial identifications and affiliations. At the height of Jim Crow, Cuba's commitment to racelessness thus seemed to offer a powerful antidote to white supremacy. It was also unique in the Latin American context, grounded not in the sexual union between races (as in the pervasive ideology of mestizaje), but rather in the transcendence of racial difference in a shared commitment to free Cuba. In this regard, Maceo represented a point of inspiration for men of color throughout the Americas, where few black heroes had been admitted to national pantheons.

Yet the apocryphal sons also offer a telling window onto Maceo's more ambivalent place in narratives of national descent. Cubans of all colors may have forged unity in the ideal of racelessness, but black men and women were rarely able to transcend the color of their skin. In a context in which racism could thwart political aspirations, the enduring reticence to scrutinize Maceo's personal life speaks volumes. To make Maceo an unassailable icon, it was necessary to bracket his embodied masculinity. Symptomatically, early historical scholarship often referred to him as "The Hero," as if his lower-case humanity were somehow beneath him.

Lionizing a nation's fathers also invited uncomfortable questions about national legitimacy and individual fidelity. As a legal category, legitimacy implied the recognition of children by their fathers, with the standing of mother and child dependent thereon. In this, Maceo's unrecognized children evoked the incomplete sovereignty of the Cuban nation. Under the regime of the Platt Amendment, Cuba was denied full independence by a paternalistic imperial 
power that justified this curtailment with reference to racial difference. Racialization and infantilization thus placed a special burden on nationalist mythologies, which had to accommodate the antiracist charge of the independence struggle and the persistent reservoirs of external and internal racism. Reverence for heroes may have offered a unifying foundation for nationalist histories. Yet the claims of apocryphal offspring threatened to undermine both individual and national legitimacies, exposing the very contingency of antiracist sovereignty.

\section{Racial Anxiety and National Paternity}

Imposters have long represented fertile territory for historians who see in the former the contours of boundaries breached and ontologies unmade. From the "false dauphins" who for decades after the French Revolution claimed to be Louis XVII, to the "Anastasias" of the deposed Russian Romanov dynasty who provoked wonder in U.S. exile, such pretenders have also shadowed political history writ large (Davis 2007; Davis 2013; Stoker 1910). The most enduring seem to condense nostalgic attachment to the political order of the past. Others have been seen as simply insane (Murat 2014). Imposters highlight the fragility of official authority and the madness of political descent: the investment of the present in an imagined past, purloined by the future. Yet they also signal a disruption of national ancestry itself, totems to what was lost, silenced, and better left forgotten (Edelman 1998).

The association between familial and national lineages is not unique to Cuba. From the paternalistic framing of colonialism to the dependence of patriotism on familial metaphors and motifs, the political has often been personalized in the language of the domestic (Hunt 2013; McClintock 1995; Stoler 2007; Stoler 2010). Moments of transformation and uncertainty are particularly ripe with these possibilities, perhaps never more so than in the birth of new nations. ${ }^{6}$ The forging of national futures may demand the silencing of an inglorious heritage, but the repressed tends to reassert itself in a similarly familial vocabulary. ${ }^{7}$

6 For recent work on Latin America and the Caribbean, see Chambers 2015, Findlay 2014, Milanich 2009, and Vasconcellos 2015.

7 In the United States, for example, the public has long manifested a fascination with the extramarital offspring of its presidents. Such stories have fed on the nation's repressed racial violence, with many early presidents rumored to have fathered children with their slaves (Lee 2013). 
We might see these stories as a counterpart to the "national romances," per Doris Sommer's classic account, that gestated within newly independent Latin American nations. Canonized love stories worked to shore up the relationship between subject and state, to "reinscribe for each future citizen the (natural and irresistible) foundational desires for/of the government in power" (Sommer 2007:31). In the late nineteenth century, Cuban writers produced their fair share of national romances. The most consequential, however, centered not domestic love but "manly union" on the battlefield, as Ada Ferrer has argued. Such stories worked to build support for the independence cause by papering over the racial divisions that had previously threatened its survival. Glorifying the shared sacrifices of black and white men in the Ten Years' War, Cuban intellectuals such as José Martí posited a "transracial Cuba," which "left intact racial categories like white and black even as it argued for their transcendence" (Ferrer 1999:126-27).

The call to overcome race thinly masked the racial inequalities that persisted only years after the formal abolition of slavery. The ideological codependence of racelessness and racial prejudice is particularly visible in the treatment afforded to Antonio Maceo. Throughout his military career, Maceo's opponents, unwilling to accept the authority of a man of color, frequently accused him of "racism" (of giving preferential treatment to black compatriots), a charge that limited his autonomy and ability to maneuver (Ferrer 1999:8284, 165-69; Roig de Leuchsenring 1945:103-8). Other black generals, including Maceo's brother José, were also subject to allegations of indecent behavior (Ferrer 1999:173-77; Sierra Madero 2006:60-73). At the very moment that white supremacy was under assault both within and beyond the Liberating Army, formulations of racelessness thus worked to silence persistent racism by portraying black Cubans as grateful to white men for their freedom (Ferrer 1999:112-41).

Overall, these writings created the conditions for imagining a nation that had purged the stain of slavery by renouncing the very boundary-racethat had sustained it. On a more figurative level, they also inverted the terms of the national romance in a way that would reverberate in Cuban political culture. It was not erotic love between men and women that sanctified the new nation, but rather the shared martyrdom of black and white men. Sex, especially the specter of black male sexuality, was repressed, at least in theory (Ferrer 1999:121). Thanatos, not Eros, would thus fuel the political life of the republic. ${ }^{8}$ 8, Valdés 1992. 
Even so, women were not absent from these wartime mythologies. The founding family of the Cuban nation depended as much on female selfabnegation as male martyrdom. Maceo's mother, Mariana Grajales, entered the nationalist pantheon on the grounds of her dedication to Cuban independence and the sacrifices it demanded, including the loss of her husband and several sons (Stoner 2003). During the twentieth century, Grajales would thus be lionized as the "mother" of Cuban independence, who had taught her sons to wield the machete (Cupull \& González 1998; Sarabia 2006; Torres Elers \& Escalona Chádez 2015). María Cabrales, Maceo's wife, would also be celebrated for her patriotic militancy and her loyalty to Maceo and his legacy (Sarabia 1976; Torres Elers 2013; Torres Elers \& Escalona Chádez 2015). The romanticization of female sacrifice thus centered the wartime deaths of husbands and sons, while conspicuously skirting the more quotidian ignominies - including infidelitythat Cuban women were expected to bear. ${ }^{9}$ As Magadalena Peñarredonda would muse in a published 1905 letter to Cabrales, "Revolutions demand great sacrifices from women and in exchange gives them little more than obscurity [olvido] and indifference." 10

The nationalist valorization of male martyrdom and female self-abnegation opened some possibilities while foreclosing others. Indeed, there were distressingly tangible consequences associated with the death of so many of the nation's patriots, especially those, like José Martí and Antonio Maceo, who had long warned about U.S. imperialism. That threat would condition the post-1898 translation of the patriotic epic, as Cubans saw a more meaningful sovereignty wither away at the hands of U.S. occupiers." The "neocolonial" Cuban nation

As Abel Sierra Madero (2006:65) has pointed out, a "double morality" prevailed within the liberating army, wherein many leaders sustained extramarital relationships while also condemning others (and especially the women involved) for engaging in this practice. On gender, race, and family formations in nineteenth-century Cuba, see Barcia et al. 20o9, Barcia Zequeira 2010, Cowling 2013, Díaz Martínez 2005, Franklin 2012, Hevia Lanier \& Rubiera Castillo 2016, Martinez-Alier 1974, Morrison 2015:106-30, Prados-Torreira 2005, and Rubiera Castillo \& Martiatu 2011. On alternative mythologies, see Lane 2010.

10 Letter from Magdalena Peñarredonda to María Cabrales, El Cubano Libre, December 9, 1904, p. 2, republished in Torres Elers 2013:356.

11 Cubans were excluded from the peace negotiations between Spain and the United States following the end of the war. Though the Teller Amendment blocked the United States from annexing Cuba, as it had Puerto Rico and other former Spanish possessions, a U.S. military occupation (1899-1902) prevented Cubans from exercising meaningful sovereignty. As a condition for withdrawal, Cubans were forced to accept the Platt Amendment, which sanctioned U.S. meddling in Cuban affairs until its final abrogation in 1934. Cuba would be subject to another U.S. military occupation from 1906-9 and other more informal interventions thereafter. 
diverged considerably from the ideal for which so many had lost their lives. And it did not help that U.S. occupation often intensified racial inequalities between white, black, and mulato Cubans. ${ }^{12}$

The masculinist national romance and its unsettling republican denouement set the stage for the emergence of Maceo's false sons, born, perhaps, out of a kind of postcolonial melancholia ${ }^{13}$ or "father hunger" in a young nation forced to stand alone in a hostile world. ${ }^{14}$ Here, journalists, politicians, and eventually historians came together to shore up Maceo's hallowed example as a foil for their political preoccupations and disappointments. Even so, debates over Maceo's sons were not merely a reflection of the conditions of Cuban independence: over and again, they provided the occasion to evaluate the legitimacy of that project. On the most basic level, filial pretenders raised doubts about Maceo's loyalty to his wife, María Cabrales, and on this ground they had to be discredited. Yet these men also evoked questions about the loyalty of individual sons to their father, and of Cubans in general to their nationalist project.

The stakes of patriotic loyalty were unmistakably weighty, particularly in light of a Plattist present. One U.S. observer went so far as to characterize the difficult circumstances faced by the widow of Antonio Maceo's brother, José, as evidence of national unfitness: "People who permit the widows and children of their dead leaders to starve are not fit to be entrusted with the responsibilities of self-government."15 Within Cuba, however, the persistence of racism represented an equally galling affront to the fight for Cuban sovereignty. The familial politics of hero worship spurred Maceo's defenders to burnish his example, but also to confront the vulnerability — racial and imperial —of nationalist mythology itself.

\section{Santiago Maceo: Violence and Empire}

In the wake of independence, a storm of American interlopers descended on Cuba: self-appointed saviors and self-interested salesmen, and more than a few who belonged to both groups. Among their number was Katherine Tingley,

\footnotetext{
12 Historians of Cuba have long debated how to measure the evolving indices of racial inequality. For an instructive juxtaposition, see Helg 1997 and de la Fuente 1999. For more on the broader context of race relations during and after U.S. occupation, see Fowler Calzada 2013:51-87 and Guridy 2010.

13 See Gilroy 2010, Krauel 2012, Mitscherlich \& Mitscherlich 1991, and Žižek 2000.

14 Per Herzog 2014.

15 See Idaho Statesman, November 4, 1898, p. 2.
} 
who had recently executed a coup within the ranks of American Theosophy, a diffuse spiritual movement of the late nineteenth century. Tingley sought a special bounty among the ruins of the independence struggle: Cuban children, the future subjects of her educational mission. Her trip would come to center on one individual in particular, a young man named Santiago, who claimed to be the son of Antonio Maceo. ${ }^{16}$

Over the course of the next decade, Santiago would become the most infamous aspiring offspring of the Cuban hero. His exploits on the frontiers of U.S. empire, connecting Tingley's Theosophist community to the PhilippineAmerican War, would draw regular attention across the Americas. Throughout his travels, Santiago would doggedly claim the mantle of Maceo's heritage, with past and future military distinction providing his most powerful evidence. From the Cuban independence struggle, in which he claimed to have fought under the assumed name of Romero ${ }^{17}$ to guerrilla warfare on the other side of the world, the young man burnished his filial credentials by reactivating their martial roots. In this, he joined a long tradition of men of color who had found in military service their most dependable, and sometimes their only, path to political ascendance.

Yet Santiago's regular appearance in transnational press circuits rarely elicited celebration from Cuban quarters. Whatever his appeal beyond the island,

16 Assessing paternity claims a century later is a complicated endeavor, and in what follows this will rarely be the focus of my analysis. A few details about Santiago may nonetheless help to establish a threshold of possibility. In April 1901 Santiago's age was reported to be 23, which would have put his birth year at 1877 or 1878 (see "Maceo's Son Is in Disgrace," Evening Sentinel, April 20, 1901, p. 4). On another occasion, he told observers that he was born in the town of Pueblo Nuevo, Matanzas ("Ultimas noticias," Diario de la Marina, October 23, 1899, p. 2). Antonio Maceo, however, did not travel to the western portion of Cuba until the final engagement of the Cuban independence struggle beginning in 1895 . He also spent roughly two months (August and September) injured and immobilized and, after the conclusion of the Ten Years' War, in exile (beginning in May 1878). Nonetheless, it is important to note that this analysis, as well as that that follows, is premised on an assumption of geographical stasis on the part of the women with whom Maceo may have transacted relationships. In the disruptive context of wartime, this was certainly not guaranteed and reflects the ascription of gendered qualities to mobility (male) versus immobility (female). I am grateful to an anonymous reader for pointing this out.

17 Santiago insisted that his father's notoriety had forced him to assume this name when he enlisted, a perhaps reasonable claim given widespread prejudice against Maceo and other leaders of color in the western portions of the island. His claim, however, is difficult to verify, given the large number of "Romero's" in the registers of the Occidente divisions of the Ejército Libertador. The only soldier with the name of "Santiago Romero" is listed with identifying details that seem disqualifying. See Indice alfabético y defunciones del ejército libertador de Cuba, commissioned by Carlos Roloff y Mialofsky (Havana: Imprenta de Rambla y Bouza, 1901). I am grateful to an anonymous reviewer for suggesting this source. 
partisans of Antonio Maceo-and, most notably, his only recognized son, Antonio Maceo Maryatt—expressed nothing but disdain for Santiago's claims and, more pointedly, his character. Throughout his many exploits, Santiago brandished force in order to tap into its presumed heroic dividends, but he tended to do so without regard for its moral consequences. His distinctly amorphous sense of nationality deviated considerably in this respect from Antonio Maceo's patriotic compass. Tellingly, the most recurrent refrain in his path through imperial warfare was duplicity, as he was accused of lying not only about his descent but also his wartime record in Cuba. Later, Santiago would even be forced out of the Philippines amidst suspicions he had collaborated with the Filipino resistance.

Santiago's personal qualities undoubtedly accounted for many of these allegations, yet they also reflect tensions inherent to the world of U.S. empire. As many have argued, the paternalism that infused the imperial project contained within it a kind of ideological duality, with "native" subjects imagined as both dutiful adherents and prodigal sons. ${ }^{18}$ Santiago's movement throughout this political landscape - as a nonwhite man whose race was often read contextually - drew out the paradoxes on which official paternalism rested, particularly the suspicion of disloyalty that dogged all of its nonwhite subjects. The varied responses to Santiago's claims refract the racial silences of the traditions he invoked, as well as the ceiling erected around full political belonging for their nonwhite partisans.

There was perhaps no more telling crucible for the Janus-faced nature of U.S. imperialism than its educational mission. The mission of pedagogical uplift would bring many Americans to postwar Cuba, and Katherine Tingley was an unconventional but by no means marginal representative of that campaign. ${ }^{19}$ She arrived in Santiago de Cuba in February 1899, only two weeks after the city was occupied by U.S. troops and quickly struck up a working relationship with the city's mayor, Emilio Bacardí. Tingley also made the acquaintance of Santiago Maceo, who was to serve as her interpreter (Greenwalt 1955:43). The young man was introduced as the "son of the slain patriot General Antonio Maceo"; 20 he was reported to have served as first a cook and then an interpreter at the number 1 commissary in Santiago. ${ }^{21}$ Santiago quickly came to occupy a central

\footnotetext{
18 On this phenomenon as it shaped the U.S. intervention in Cuba, as well as its gendered dimensions, see Hoganson 1998, Lucero 2018, and Pérez 2008.

19 For more on this dynamic, see Lucero 2015.

20 "Mrs. Katherine Tingley. Noted Educator and Philanthropist Arrives in Havana With Her Party," La Lucha, April 27, 1906, p. 1.

21 "Maceo's Son Seeks Education," Chicago Daily Tribune, October 15, 1899, p. 3; "Maceo's Son
} 
role in Tingley's preparation of a "Liberty Day" for Cuban children, a proposal endorsed by General Wood and Mayor Bacardí. ${ }^{22}$ Capping the heavy-handed pageantry, he was asked to "[plant] two trees to represent Cuba and the United States" (Greenwalt 1955:44).

The prominence afforded to Santiago in Tingley's plans would only expand in the ceremony's aftermath. The Theosophist leader encouraged him to accompany her back to California. Santiago, one newspaper reported, would travel to the United States for the purpose of learning the "methods used in the various relations of life among the people of the United States, so that he may return to his own people and help them to take the right advantage of their new-found liberty."23 The young man would be one of the star attractions at the Point Loma opening ceremonies held in April 1899, where he was presented as an ardent convert to Tingley's mission. ${ }^{24}$

Yet the relationship between Santiago and Tingley quickly soured, escalating into a public battle. Santiago alleged that Tingley had planned to use him as an "advertisement" for Theosophy, but her disappointment with him had led her to "discard" him shortly after the group's arrival in British Columbia. She went so far as to register him as a "servant" for one of the men accompanying her, Santiago charged, something to which he "made very strong objection." ${ }^{25}$ In contrast, Tingley maintained that she had displayed nothing but charitable intentions toward the young Cuban. The same impulse had inspired her to bring him to the United States with her, but he had responded, she claimed, with "vanity" and ingratitude, falling "into disrepute at different places which they visited by borrowing money and failing to return it."26 "So far as his lineage is concerned," Tingley maintained, "he is the son of a gallant man, a patriot, but I regret to say he has but little of his father's traits in his character."27

Is in Disgrace," San Francisco Chronicle, April 19, 1901, p. 7. In Santiago, Maceo seems to have worked most directly with Colonel Hugh Gallagher, who served as Major of the Chief Commissary of Subsistence under General Leonard Wood. See Colonel Duvall to Adjutant General of the United States, San Francisco, November 15, 1899, Entry 25, Box 1974, File 295212, Records of the Adjutant General's Office, 1780's-1917, Record Group 94, National Archives Building, Washington DC. I am grateful to Jonathan Deiss for his assistance in locating this and subsequent information about Santiago's military record.

22 New Century II (March 18, 1899), p. 6, reprinted in Greenwalt 1955:44.

23 "Brotherhood Meeting: Opening Congress to Be Held at Point Loma Thursday," Los Angeles Herald, April 10, 1899, p. 5.

24 "The Theosophists: Listen to Reports of the Work Done," Los Angeles Herald, April 16, 1899, p. 4; "San Diego County. Special Train Filled with Theosophists," Los Angeles Times, April 13, 1899, p. 13.

"Mrs. Tingley and Maceo's Son at Outs," San Francisco Chronicle, May 24, 1899, p. 4. "Mrs. Tingley and Maceo's Son at Outs," San Francisco Chronicle, May 24, 1899, p. 4. 
Where Santiago had imagined a partnership, filial in form, Tingley's paternalism ultimately took a more domineering form. Santiago suspected, even at this early stage, that his color had something to do with this gap. ${ }^{28}$ Nonetheless, even after his break with her, the young man's ambitions would continue to be channeled through U.S. imperialism. Over the next few years, he would feed his growing celebrity with two contradictory claims. On the one hand, he drew popular attention with stories about his heroism in the Cuban war of independence and his maceísta heritage. On the other hand, he married those assertions to his plan to achieve further glory by fighting on behalf of the U.S. imperial project in the Philippines, where a guerrilla struggle continued to rage. But the integrity of both narratives would be threatened by persistent allegations of duplicity. For his critics, Santiago's mobilization of indiscriminate violence constituted the most damning evidence thereof.

The first such accusation emerged from Spokane, Washington, where Santiago had settled after breaking with Tingley. ${ }^{29}$ There, he had become involved with the local chapter of a Christian philanthropic organization. His supporters were quick to bail him out after he was arrested (by Buffalo Bill Cody's nephew, no less) for threatening to shoot a waiter who had asked him to move from a café table. ${ }^{30}$ In this instance, Santiago once again bristled at the structures of overt racism, telling a reporter that "such a thing as being asked to sit apart because his skin was dark never happened to him before."31 Less than a month later, Santiago was making headlines for promising to use his machete on another member of his volunteer group..$^{32}$ By this time, he had had begun to present himself as a former lieutenant in the Cuban army, offering public lectures on Cuba and collaborating with the local Red Cross. Santiago denied the latest allegations, insisting that he had only threatened to "beat [the man's] head against the wall," not kill him. After all, he added, he was a "Christian."33

Seattle Daily Times, May 23, 1899, p. 5; "Maceo as an Advertisement," Salt Lake Herald, May 24, 1899; and "The Theosophists and Maceo," Denver Post, June 3, 1899, p. 3.

28 "Maceo's Son Mourns," Daily Intelligencer, May 22, 1899, p. 13.

29 On class and racial divisions and mobility in the U.S. West, see Paddison 2012 and Smith 2015. I am grateful to Anne Eller for suggesting these sources.

30 "General Maceo's Son Arrested: Charged with Threats Against Life," San Francisco Call, August 31, 1899, p. 3.

31 "Lieut. Maceo," State Rights Democrat, September 1, 1899, p. 12. See also "His Feelings Hurt Again," Daily Intelligencer, August 31, 1899, p. 4.

32 "Lieut. Maceo's Ire: Dashing Cuban Lieutenant Falls from Grace," Los Angeles Times, September 22, 1899, p. 3 .

33 "Lieut. Maceo's Ire: Dashing Cuban Lieutenant Falls from Grace," Los Angeles Times, September 22, 1899, p. 3 . 
Perhaps these not infrequent run-ins with the law inspired Santiago's next move: in late September or early October 1899, he attempted to join up with a Minnesota regiment that had recently returned from the Philippines. He regaled spectators in that state with stories of his wartime heroics and even marched in a military parade. ${ }^{34}$ Santiago had managed to entrance many around him with his "amazing [talking]" and his "anecdotes of hand-to-hand encounters with the Spaniards." 35 His powers of persuasion even extended to a Filipino man who had returned with the Minnesota unit. Together, they dreamed of enacting revenge on Emilio Aguinaldo, leader of the insurgency against U.S. occupation and future first president of the Philippines. But loyalty to U.S. empire was at the forefront of Santiago's public declarations, in which he insisted on his debt to the Americans for their intervention in Cuba. "I know my father would commend my action were he alive," Santiago maintained, "The Philippine islanders are far less fitted for self-government than the Cubans." ${ }^{36}$

But Minnesota Governor John Lind, who had served in Cuba himself, came to have doubts about Santiago's spectacular claims. Seeking confirmation, he wrote to Military Governor John Brooke in Cuba. The reply was quick to come: "Alejandro Rodriguez and other Cuban leaders say that Maceo had no son."37 Meanwhile, Lind's letter provoked a broader investigation in Cuba, reaching Maceo's former comrades and high-ranking members of the Cuban Liberating Army. Santiago Maceo would soon be denounced as an "imposter" in the pages of El Cubano Libre, a newspaper in Santiago de Cuba. ${ }^{38}$ In a letter, future Cuban President Mario García Menocal also raised questions about Santiago's parentage, insisting that it was "generally understood by all those who were well acquainted with him that Gen. Maceo never had children; although in one case in Jamaica a boy born to an English woman, he thought, was his, and this was eighteen years ago." Another former comrade, General Lacret Morlot, seconded these concerns, branding Santiago an "illegitimate son, which fact ... should not be permitted to militate against him."39

Yet the controversy over Santiago's "legitimacy" did not prevent him from pursuing his long-sought deployment to Manila, albeit not as an enlisted soldier. In the Philippines, Santiago would quickly come to distinguish himself,

"Maceo's Son Seeks Education," Chicago Daily Tribune, October 15, 1899, p. 3.

"Gen. Maceo Had No Son," The Chronicle (Spokane WA), October 31, 1899, p. 7.

36 "Maceo's Son Aims High," Omaha Daily Bee, October 24, 1899, p. 11.

37 "Gen. Maceo Had No Son," The Chronicle, October 31, 1899, p. 7. It seems plausible that Antonio Maceo Maryatt was first publicly identified as Maceo's son as a result of Santiago's pretensions.

38 "Insular Items of Interest," Diario de la Marina, November 1, 1899, p. 1.

39 "Santiago's Bar Sinister," Saint Paul Globe, November 19, 1899, p. 3.
} 
most likely as an interpreter with the Macabebe Scouts, an irregular civilian corps of Filipinos contracted to help the U.S. Army stamp out the guerrilla resistance. ${ }^{40}$ The Scouts, later to be formally incorporated into the Army as the "Philippine Scouts," would play a central role in apprehending Aguinaldo in March 1901. They did so by posing as Tagalog-speaking reinforcements sent for by the insurgent leader. ${ }^{41}$ But Santiago's glory would prove fleeting. Immediately following Aguinaldo's capture, he would be arrested by his one-time collaborators in the U.S. military on the suspicion that he had been providing information to the insurgent forces.

These accusations (or perhaps Santiago's indigence) would ultimately lead to his removal from the Philippines. He next resurfaced behind bars at Alcatraz. ${ }^{42}$ Santiago, however, refused to relinquish his claims to grandeur. Though disappointed by his experience in the Philippines, the young man assured reporters that his Cuban countrymen would greet him with "enthusiasm" if he were to return. ${ }^{43}$ That proclamation would soon be countered by another rebuttal of Santiago's filial claims, this time from the mouth of Antonio Maceo's only recognized son, speaking to journalists from his college preparatory course in Ithaca, New York. ${ }^{44}$

$40 \quad$ "Personalities," Diario de la Marina, November 3, 1899, p. 1. Colonel Duvall of the 48th Regiment U.S. Volunteer Infantry, an African-American unit, did attempt to formally enlist Santiago. See Colonel Duvall to Adjutant General of the United States, San Francisco, November 15, 1899. Santiago, however, does not seem to have enlisted. Instead, he may have traveled to the Philippines aboard the USAT Indiana, which brought the 4oth U.S. Volunteer Infantry to the Philippines in late November 1899. Roughly a monthly later, Santiago was admitted to the hospital of the 4oth Volunteer Infantry with measles. See Hospital Records [Santiago Maceo], Manila, December 20-23, 1899, Entry 540, Box 27, Records of the Adjutant General's Office, 1780's-1917, Record Group 94, National Archives Building, Washington, DC. But Santiago was not a formally enlisted member of the 4oth either, and some even suspected he had traveled aboard the USAT Indiana as a stowaway. See "Stranger to Both Fear and Mercy," St. Louis Republic, April 28, 19o1, p. 37.

Flake 2009. Santiago Maceo would later insist he had served as an officer in the Scouts. This claim is dubious, and Santiago does not appear in a photograph of the army officers aboard the ship that brought the Macabebe Scouts to Palanan, Isabela, for the Aguinaldo mission, see Flake 2009:6o. But it is possible that Santiago made it to the Macabebes after meeting Burton J. Mitchel aboard the USAT Indiana. Mitchel was a participant in the action in which Aguinaldo was captured. See "Special Field Return of U.S. troops on board U.S. Transport 'Indiana' enroute from San Francisco Cal. for Manila P.I.," November 23, 1899, Entry 74, Box 1, Records of the Office of the Quartermaster General, 1774-1985, Record Group 92, National Archives Building, Washington, DC. "Maceo's Son Is in Disgrace"; "Un deportado," La Lucha, April 20, 1901, p. 2; and "El hijo de Maceo en Filipinas," El Tiempo (Caracas), April 26, 1901, p. 3.

43 Quoted in "El hijo de Maceo en Filipinas," El Tiempo, April 26, 19o1, p. 3.

44 "Not Gen. Maceo's Son," Indianapolis Journal, April 21, 1901, p. 1. 
Santiago's experiences in the Philippines must be situated within the tormented history of racism in the U.S. Army. African American men had fought with distinction in the first stage of U.S. imperial warfare in Cuba (and, before that, on the Western frontier), many motivated by their commitment to the island's liberation. At a time of intensifying discrimination within the United States, black soldiers also viewed enlistment as an avenue to mobility, despite the obvious contradictions between imperial rhetoric and Jim Crow racism. The expected opportunities for promotion, however, rarely materialized. That did not prevent other black men from joining up as volunteers in the following years, but they, too, found racial discrimination within the army to be the norm. This experience, alongside longstanding opposition to imperial extension, led many African American leaders to condemn the later Philippine campaign. Nonetheless, in 1899, the four black regiments that had fought in Cuba were mobilized once more (Gatewood 1999:8-16; Jimoh \& Hamlin 2015:2039).

As they had in Cuba, black soldiers developed complex feelings of solidarity and sympathy with the Filipinos they encountered. In some ways, this identification was an asset to the army, which used African Americans to establish confidence and good relations with the local population. Almost immediately, however, it also became an object of suspicion. This extended to concerns about the national loyalties of black soldiers, which apparently led occupation governor William Howard Taft to order the premature withdrawal of black soldiers from the Philippines (Gatewood 1999:239-45).

Where master narratives of benevolent oversight foundered on the realities of white supremacy, the specter of disloyalty condensed the irreconcilable contradictions of the imperial project. The underlying violence of that endeavor was warded off by projective measures: it was the enemies of empire, not its acolytes, who would be accused of ruthlessness. Nonwhite allies would be tailed by similar suspicions, most notably the Macabebe Scouts, who became infamous for their allegedly ruthless tactics. The U.S. occupation of the Philippines, like its counterparts in Cuba and elsewhere, thus generated new channels of racialization, which at once drew on while also foreswearing the overall arc of imperial violence (Kramer 2006). In the logic of U.S. extension, brutality became the rhetorical province of nonwhite soldiers and civilians, which served to obscure the violence of imperialism itself.

Santiago's path through U.S. empire seems to unite these two constructions of violence, as he was both celebrated and condemned for his martial zeal. As First Lieutenant General Whipsett, former Adjutant of the Macabebe Scouts, would put it, "I never saw a man more utterly regardless of life." Santiago, Whipsett continued, "seemed to hate the Tagals worse than he did the 
Spaniards." ${ }^{25}$ In the years to come, Santiago's quest for martial glory would bring him back to the Philippines as an irregular employee of the U.S. Army. ${ }^{46}$ Yet the more ambivalent implications of Santiago's propensity to violence also surfaced elsewhere. We need only look to the divorce proceedings initiated in 1902 by his new wife, Ethyle Maceo, who "[alleged] that he [had] without cause or provocation cruelly beaten and abused her almost daily since their marriage." 47

The "transitivity" of colonial violence perhaps binds four centuries of Spanish empire in Cuba to the anticolonial struggle of Antonio Maceo and his comrades (Butler 2015:184; Fanon 2011). By this logic, only the fearless, if selfimmolating, militancy of the liberating army could right the wrongs of Spanish colonialism. We might be tempted to see in Santiago Maceo's journey through U.S. empire a perverse reflection of such righteous warfare, beginning with his imperial "adoption" and culminating in wanton brutality waged on its behalf. In his hands, we find a propensity to violence that, absent ideological commitment, had become its own raison d'être and his only real claim to notoriety.

As we have seen, Santiago's very celebrity provoked discussions among Maceo's defenders on the island as to whether he had fathered any children and, if so, whether Santiago could be one of them. The resulting deliberations - and the unanimity of their response-represent an important early moment in the elaboration of Maceo's lineage. Santiago's claims also brought into the open musings about the "Jamaican" son whom Maceo had recognized. At multiple conjunctures, Antonio Maceo Maryatt himself entered the conversation to defend his filial prerogatives.

Yet the transnational arc of this debate insinuated an unwelcome third party into nationalist constructions. Santiago's ability to mobilize press attention by making claims on Maceo's descent-even as he seemed to defy its political content—highlights the imperial limits on Cuban self-fashioning. In Santiago's hands, the island's patriotic epic was contorted into all manner of contrary positions, silencing Maceo's ideological program in the service of palatably proU.S. messaging. Santiago, however, did not enjoy unlimited narrative license. The racial contours of these battles, in which Santiago chafed over and again at

45 "Stranger to Both Fear and Mercy," St. Louis Republic, April 28, 1901, p. 37.

46 Santiago Maceo, Admission Records to Military Hospital, Camp McGrath, Philippines, November 16, 1907, and Post Hospital, Camp Stotsenburg, Pampanga Province, Philippines, March 22 and 30, 1910; Entry 540, Box 27, Records of the Adjutant General's Office, 1780's-1917, Record Group 94, National Archives Building, Washington, DC.

San Francisco Call Bulletin, May 1, 19o2, volume 91, p. 9. 
the structures of Jim Crow segregation, would prove one of the most enduring brakes on nationalist assertion-both outside Cuba and, more gallingly, within.

No son, real or fictive, would more vividly confront the racial constraints of Cuba's postcoloniality than Antonio Maceo Maryatt, born in 1881 in Kingston, Jamaica, to Amelia Maryatt, Maceo's longtime lover. Over the course of his American travels, Maceo would visit his son several times in Jamaica and finally, after the "mysterious disappearance of the child's mother," in Costa Rica in 1891 (Cremata Ferrán 2005). They would remain there together until 1895, when Maceo departed once more to join the independence struggle in Cuba. Before leaving, he made plans for his son's future education. In 1897, Maceo's son, or "Antoñito" as he was affectionately called, traveled to Ithaca, New York, to enter high school and finally Cornell University, where he would study engineering. After graduation, he returned to Cuba to live a modest and mostly quiet life, serving as a member of the Liberal Party and an engineer employed by the Department of Public Works (Cremata Ferrán 2005; Torres Elers 2006).

Yet the very fact of Maceo Maryatt's transnational movement, like that of Santiago before him, opened up room for confusion, reinvention, and press scrutiny. Journalists in Cuba and the United States devoted frequent attention to Maceo's son, including his progress through Cornell and his subsequent marriage to a local Ithaca woman..$^{48}$ In both countries, however, they also continued to cover the determined field of aspiring sons. One young man, institutionalized in a New York psychiatric hospital, would even claim to be Maceo Maryatt himself.

These pretenders, like Santiago before them, drew out the tensions bound up in Antoñito's status as a recognized son. To what was he entitled? What, in turn, did he owe? Both questions implicitly pivoted on the question of race. Maceo Maryatt attended college in the United States in the age of Jim Crow, and he returned to a Cuba struggling to accommodate the antiracist charge of its independence struggle. He did so as a man of color whose father had been both lionized and persecuted for his commitment to racial equality. But the

48 "El hijo de Maceo," La Lucha, June 20, 1904, p. 2; "El hijo de Maceo es huésped de La Habana," El Mundo, June 13, 1913, p. 1; "El hijo de Maceo," La Lucha, August 2, 1905, 1; and "Se ha casado el hijo del general Maceo," Diario del Salvador (San Salvador, El Salvador), June 23, 1908, p. 4. 
very diversity of this political landscape guaranteed that Antoñito's race would be read contextually. Over the course of his youth, Maceo Maryatt consistently expressed unease about his racial identity, even as others placed it at the core of his father's inheritance to him.

Debates over this legacy dated back to Maceo Maryatt's days as a student in New York, where his education was managed by the Cuban Educational Association (CEA) in dialogue with future Cuban President Tomás Estrada Palma. In commending Maceo Maryatt to an instructor at Cornell University, representatives of the CEA praised the young man as an "apt, malleable student" with "sufficient brain and brawn to develop into as great a man as his illustrious father." ${ }^{49}$ But assessments of Maceo Maryatt's aptitudes quickly became entangled with his financial circumstances and racial identity. A letter from Professor J.M. Jenks of Cornell noted his "apparent disinclination to work with his hands" in contrast to the alleged "eagerness" of the "many white students" on campus. ${ }^{50}$ Tensions with his patrons lurked beneath the surface of these statements, as they urged him to "work still more"51 in response to his feelings of "[discouragement] about his expenses." ${ }^{2}$ By the following month, these exchanges had turned openly racist. As one statement attributed to Maceo's high school principal, F.D. Boynton, sneered, "your little man in black has not a sufficient supply of gray matter to warrant his attempting a double task, namely, that of doing full intellectual work and much physical labor at the same time."53

Years later, such racist sentiment would erupt publicly in response to Maceo Maryatt's wedding to Alice Mackle, a local New York woman. ${ }^{54}$ Mackle was White, and that fact had provoked a small storm, particularly among her relatives, who refused to support the marriage out of the belief that the "introduction of [black] blood" into their family would cause "harm ... or irreparable

49 Letter from Gilbert Harroun to Dr. Shaw, March 9, 190o, New York City, Box 3, Records of the Cuban Educational Association of the United States of America, 1897-1954, Division of Manuscripts, U.S. Library of Congress, Washington, D.C. I am grateful to Marial Iglesias Utset for sharing these documents with me.

$5^{\circ}$ Letter from J.M. Jenks to Gilbert Harroun, May 2, 19oo, Ithaca NY, Box 3, Records of the Cuban Educational Association.

$5^{1}$ Letter from J.M. Jenks to Antonio Maceo, May 23, 19oo, Ithaca NY, Box 3, Records of the Cuban Educational Association.

52 Letter from A.C. Foote to Prof. F.D. Boynton, May 7, 190o, Ithaca NY, Box 3, Records of the Cuban Educational Association.

53 Memo from F.D. Boynton to Gilbert Harroun, received June 4, 190o, Ithaca NY, Box 3, Records of the Cuban Educational Association. For more on the CEA, see Jarvinen 2012.

54 In Cuba, she would soon give birth to a son, Antonio Maceo Mackle, future surgeon and celebrated leader of the Cuban community in South Florida exile. 
damages." ${ }^{55}$ Alice's family put up such a fight that the couple was unable to wed in the Catholic Church, even after a bishop insisted that the "church had no power to refuse to countenance a marriage between a negro and a white woman. ${ }^{56}$ Press accounts of the wedding minced no words in describing them as "Joseph Antonio Maceo, dark-skinned, kinky-haired and with every feature seeming to betray Ethiopian blood, and Alice Isabel Mackley, white, with waving blond hair and a general air of delicacy and refinement."57

Antoñito's racial difference would haunt him for years to come. Perhaps in response, he began to insist that he was "Spanish and not Cuban."58 Straddling the color line in this way would not, of course, have been out of step with the racial mores of republican Cuba. There, a discursive consensus on racelessness created room for many to cross color lines, even as a robust middle class of color forged spaces of respectability within blackness. ${ }^{59}$ It did, however, strike at least one black American as an affront to Maceo's legacy. Several decades later, an African American correspondent in Havana would lament that Maceo Maryatt now lived "[passing] for white": "Of course, he has a government job. He went to school in America and is married to a white girl from Syracuse, NY. That is not a crime, of course; but this man, whose mother and father were both Negroes, has been trying to forget that he is colored, shuns the people of his father's blood ... by trying to pass for white, where it is absolutely unnecessary to do so." 60

Yet it was not U.S. racism alone, perhaps, that inspired Maceo's racial ambivalence. Throughout his lifetime, the treatment afforded to Antoñito was often used as a barometer of fidelity to Maceo's legacy, with racism a frequent undercurrent of such conversations. Most famously, Tomás Estrada Palma served as the young man's guardian early in his education after Maceo's family was no longer able to do so. For this, he would receive the private reproach of Maceo's

"Se ha casado el hijo del general Maceo" Diario del Salvador, June 23, 19o8, p. 4. See also "Son of Maceo Takes White Girl as His Bride," The Lowell Sun, May 30, 1908, [pg. no. unclear].

56 “Maceo's Bride White," Washington Post, May 29, 19o8, p. 1.

57 "Son of Maceo Takes White Girl as His Bride," The Lowell Sun, May 30, 1908.

$5^{8}$ "Se ha casado el hijo del general Maceo," Diario del Salvador, June 23, 19o8, p. 4. Ship logs charting the young man's trips to and from the United States reflect the fungibility of his racial identity, which was at least once recorded as "African" but just as often as "Cuban." See the Ancestry.com online database, "New York, Passenger Lists, 1820-1957," https://search.ancestry.com/search/db.aspx?dbid=7488, accessed 26 November 2018.

59 On the latter phenomenon, see Pappademos 2014.

6o William Pickens, "Darker Cubans Suffer from U.S. Color Line," Afro-American (Baltimore MD), September 27, 1930, p. 3 . 
widow, María Cabrales, who in June 1901 wrote Estrada Palma to request funds and inquire whether he had, as she read in a Santiago de Cuba newspaper, taken charge of Maceo Maryatt's education. "Prudence and extreme protectiveness [celo] around the good name of Maceo forced me to maintain silence in the face of such a terrible reality," Cabrales continued indignantly, "and from this that he be allowed to present himself as a natural son." Estrada Palma apparently responded by sending US $\$ 200$ to Cabrales, whom he noted was "indignant because I maintain in high school the son of Antonio Maceo whom she calls adulterous." 61

Yet whether Cuba's first president continued to look after the son who had caused such pain to his friend is unclear. On more than one occasion, Antoñito found himself short of funds to continue his university education, ${ }^{62}$ and at one point Estrada Palma himself indicated that he would be unable to contribute any longer. ${ }^{63}$ This inspired some of Estrada Palma's foes in the Liberal Party to raise questions about how well he treated Maceo's son in practice. A 1905 speech by Liberal war hero and antiracist activist Generoso Campos Marquetti insinuated that race might have informed Estrada Palma's shifting attitude toward his charge. ${ }^{64}$

These debates would persist long after Antoñito's return to Cuba. For years to come, Campos Marquetti would continue to advocate for support for Antoñito's education and family. ${ }^{65}$ In 1916 , the Cuban Congress finally approved a credit for him to purchase a home while he finished his professional training in Havana. ${ }^{66}$ Even that determination, however, provoked disagreement over whether the title to such a property should be granted in perpetuity to Maceo Maryatt's descendants, or in a more finite sense. Ultimately, several senators successfully argued that their decision on this seemingly arcane point should be understood as a test of their reverence toward Maceo's literal and metaphorical heirs.

In the United States, the discrimination Antoñito experienced was explicit and bald. As a black man, he was not afforded the privileges his heritage guar-

61 Letter from María Cabrales to Tomás Estrada Palma, June 27, 19o1, Santiago de Cuba, Archivo del Museo Provincial de Granma, Colección Tomás Estrada Palma, leg. 3, no. 897, reprinted in Torres Elers 2013:348.

62 Diario de sesiones del Senado, República de Cuba XXX, no. 115, Thirtieth Legislature, May 17, 1916, Havana: Rambla y Bouza, 12, accessed at http://ufdc.ufl.edu/UFooo72699/oooo1.

63 Letter from Gilbert Harroun to Dr. Shaw, March 9, 1900.

64 "De Matanzas. Espléndido Mitín," La Lucha, November 4, 1905, p. 5.

65 "El hijo de Maceo es huésped de La Habana," El Mundo, June 13, 1913, p. 1.

66 Diario de sesiones del Senado, República de Cuba XXX, no. 115, 10; see also Cremata Ferrán 2005 . 
anteed him in Cuba. Yet the racial landscape Maceo Maryatt navigated on the island was not altogether congenial. The years following his return witnessed contentious battles over racial inequality. In 19o8, a group of Afro-Cubans came together to form the Partido Independiente de Color (PIC), perhaps the first political party in the hemisphere to mobilize on behalf of black rights. But it was party activists - and not those they sought to challenge - who would be greeted with charges of "racism" as a result of their activism against lingering racial inequities. In response, the PIC staged an uprising, which was met with violent repression (de la Fuente 2001; Helg 1995; Portuondo Linares 1950).

These events hold up a mirror to the more quotidian racism that Maceo's son and other Cubans of color experienced in early republican Cuba. Since his time in New York, Antoñito had confronted the political implications of his blackness. A shared racist context - explicit in the United States and submerged but no less palpable on the island-informed the young man's relationship to his birthright. This transnational preoccupation with Antonio's race would come to a head with the appearance of an uncanny double. In 1913, a young man who identified himself as Antonio Maceo was institutionalized in a New York mental asylum. Newspapers reported that he had been driven mad by racism itself.

It is hard to establish with certainty the identity of this "Antonio Maceo," but he may have been "Daniel Maceo," who surfaced in the California press around 1908. Reporters had flocked to the side of a man claiming to be Maceo's youngest son, who announced that he had assembled a force to "drive out the French and other foreigners who [were] bent on conquest from Tangier and Africa." Proclaiming the cause of an "Africa for Africans," Daniel Maceo planned to recruit "100,00o men" to defend the "moral and political right" of Ethiopians to claim Africa for themselves. Here, we have a suggestive contraposition to Santiago's pro-imperial posturing. ${ }^{67}$

Unlike Santiago, however, Daniel appears not to have made it very far, judging by his reappearance roughly a year later at the helm of the "EthiopianSteamship Company" in Los Angeles. ${ }^{68}$ Passing himself off as an "outlawed Duke of Pinar del Río [Cuba's westernmost province]," Daniel had risen within the company's ranks. ${ }^{69}$ But his ascent would be short lived. When Daniel insisted that he had been sent, as a member of the Cuban Senate, to "inspect consulates for the Cuban government," he aroused the suspicions of the local Cuban consul, who went to interview Daniel and reported dismay at finding a

67 "Son of General to Aid the Moors," San Francisco Chronicle, February 11, 1908, p. 4.

68 "News and Business," Los Angeles Times, August 6, 19o9, p. 114.

69 "Negro 'Duke' Loses Rank," Los Angeles Times, August 28, 1909, p. 17. 
"negro of little education ... passing himself off as a representative of the little republic."70 Soon thereafter, the Los Angeles Times ran an exposé on Daniel, downgrading him to a mere "Pullman car porter." ${ }^{\text {"1 }}$ Ultimately, Daniel would be arrested on swindling charges and "charged ... with insanity and threats to kill" one of the men "who brought about his downfall." 72 Authorities transferred him to hospital, where he awaited an appearance before the Lunacy Commission.

From one insanity charge to another we might follow his path: "Antonio Maceo" next appeared behind the walls of a mental hospital in Long Island, New York. The alarm went out in a June 1913 cablegram, announcing that Antonio Maceo, son of the "great Cuban patriot of the same name," had disappeared from the psychiatric hospital he had entered the previous September. ${ }^{73} \mathrm{He}$ had reportedly been admitted under an assumed name due to a "nervous depression" and "attacks of melancholy." When Cuban officials in New York became aware of his presence there, they dispatched an "agent with orders to investigate the state in which the patient found himself and propose his transfer to a private institution." ${ }^{74}$ U.S. journalists were more forthcoming than their Cuban counterparts in revealing the reason behind Maceo's alleged institutionalization: "Young Maceo, it was said, had an hallucination that the people in New York were calling him 'nigger." "75

In Cuba, the case would quickly develop into a test of devotion to Maceo's legacy. Throughout the controversy, the U.S. press accepted without question that the twenty-two-year-old man was indeed the son of Antonio Maceo. So too did the Cuban press, at least at first. But the reaction on the island would quickly change to suspicion, and finally condemnation. Leading the charge were Antoñito's supporters among the island's most prominent Afro-Cuban patriots. They sought not only to dispel the rumors as false, but also to paint their dissemination as an act of infidelity to Maceo's memory.

A skeptical reporter went to interview Generoso Campos Marquetti who had recently argued in favor of a state pension for Antoñito. Campos Marquetti offered an unequivocal denial: Maceo's son, he insisted, "was in Havana, and the fine state of his mental faculties was unquestionable."76 $\mathrm{He}$ was seconded in his assertion by another veteran, who posited that the institutionalized "Maceo"

\footnotetext{
$70 \quad$ "Negro Shark in Shackles," Los Angeles Times, December 30, 1909, p. 111.

71 “Negro 'Duke' Loses Rank," Los Angeles Times, August 28, 1909, p. 17.

72 "Negro Shark in Shackles," Los Angeles Times, December 30, 19०9, p. 111.

73 "Desapareció Maceo," El Mundo, June 13, 1913, p. 13.

74 "Desapareció Maceo," El Mundo, June 13, 1913, p. 13.

75 “Maceo's Son Flees Asylum for Insane," New York Tribune, June 12, 1913, p. 1.; see also "El hijo de un héroe," El Universal (Caracas), July 6, 1913, p. 2.

76 "El hijo de Maceo es huésped de La Habana," El Mundo, June 13, 1913, p. 1.
} 
was a "canard or perhaps some madman who had invoked the legendary name of Maceo when he entered the hospital." ${ }^{\prime 7}$ But the most decisive rebuttal came from the Antonio Maceo's onetime confidant, Silverio Sánchez Figueras, who noted in a published letter that his communication with Antoñito had been "extremely frequent" since he returned to live in Havana. ${ }^{78}$ Sánchez Figueras also offered an alternative theory: perhaps "Antonio Maceo" was none other than Santiago Maceo. Santiago, he added, had figured among the "blind troops" that had collaborated with the U.S. intervention in Cuba, only to end up fighting in the Philippines, from which he was later expelled. Any claim to the contrary, Sánchez Figueras concluded, was a reflection of "ignorance or depravity [in trying] to obscure who was the true son of [his] old chief, brother-in-arms and dear friend, general Antonio Maceo." ${ }^{\prime 9}$ As these speculations suggest, more than one apocryphal son found his place in Cuba's living memory, and could be resurrected to invalidate new claims as they arose.

For Maceo's real and false sons, blackness sat at the core of their familial legacy. We might say that all the sons were, in this way, "overdetermined from without" (Fanon 2017:198). But in the transnational circuits of Cuban postcoloniality, blackness was also an instrument that unmade selves. From Santiago to Antonio (or his double) and Daniel, we can follow the course of racial alienation, which left in its wake a succession of shape-shifting subjects. The process of racial translation between the United States and Cuba was perhaps most fraught where the politics of U.S. empire met the lived experience of blackness in motion. ${ }^{80}$

As Frank Guridy has argued, this shared experience of racial discrimination contributed to the "forging of Afro-diasporic linkages" between the United States and Cuba (Guridy 2010:11). It was, at the end, the only inheritance that bonded Maceo to his false sons, too. But the pretenders' insistence in claiming this "father" also points to another conclusion. Maceo's mythologized name, wielded like a totem, could offer a powerful defense against the indignities of bigotry. Increasingly, that would be a strategy adapted by Cuban historians as well.

77 "El hijo de Maceo es huésped de La Habana," El Mundo, June 13, 1913, p. 1.

78 Silverio Sánchez Figueras, "El hijo de Antonio Maceo. Carta abierta," El Mundo, June 14, 1913, p. 7 .

79 Sánchez Figueras, "El hijo de Antonio Maceo. Carta abierta," El Mundo, June 14, 1913, p. 7.

8o See Greenbaum 2002, Grillo 200o, Guridy 2010, and Putnam 2013. 


\section{Gregorio Bustamante Maceo: the Historical Heritage of a Name}

General Maceo: Boy, I've heard that you claim to be my son.

Captain Ahumada: It's true, General; I'm your son.

General Maceo: And how do you know that?

Captain Ahumada: Because my mother told me so, she swore to it.

General Maceo: What's your mother's name?

Captain Ahumada: Fulana de tal [a common Cuban expression meaning "Jane Smith"].

General Maceo: Well I don't remember anyone by that name. Give me some other detail; where did I meet her? What year were you born?

Captain Ahumada: In Mayarí, General. I was born in such-and-such year.

General Maceo: Some years after I was in Mayarí, then, so, you can't be my son, and I forbid you to give yourself that title. ${ }^{81}$

The flood of imposter sons began even before Maceo's death. One such aspirant was Ramón Ahumada, described as an "elegant young man, nearly six feet tall, and a light-skinned mulatto [blanconazo]" (Souza 1951:35). When Maceo heard of his claims, he demanded that Ahumada appear before him. Without denying the insinuation of an extramarital liaison, Maceo drew on his own biography to nullify Ahumada's claims. The shape of the conversation introduces a novel generic motif: historical reasoning would provide the most potent weapon against the pretensions of aspiring sons.

Several decades later, the historicist paradigm of familial defense would face its greatest test. In 1951, a retired Honduran soldier by the name of Gregorio Bustamante (Maceo) would enthrall Cubans with his insistence that he, too, could lay claim to Maceo's paternity. Tensions over Bustamante's assertions would come to a head when a group of Cuban reporters decided to bring him to Cuba, where he traveled to affirm his maceista lineage. This trip would, in the words of a historian, Emilio Roig de Leuchsenring, usher in "extraordinary repercussions in our Republic and throughout the Continent."82

In response, a recently professionalized cohort of Cuban historians would mobilize to discredit Bustamante. Gregorio's efforts thus prompted a historiographical shift akin to popular conversations of the previous decades. As

$81 \quad$ Quoted in Souza 1951:35.

82 Roig de Leuchsenring 1951:7. I first learned about the controversy over Gregorio Bustamante and its associated publications in Cremata Ferrán 2005. 
a generation of revisionist scholars confronted Cuba's republican disappointments, they found in Antonio Maceo a source of counterfactual inspiration. But renewed attention to Maceo's political example also demanded the sanitization of his biography. In their efforts to counter Bustamante's pretensions, Cuban historians united the project of historical writing with the defense of patriotic heroes. They thereby banished the ambiguities of their intimate lives to the historiographical margins.

Bustamante's 1951 pilgrimage to Cuba brought this process to a head, following a campaign spanning more than a decade. Gregorio first came to public attention in 1938, thanks to his encounter with the Cuban team at the Central American Olympics. There, the island athletes heard Bustamante defend their country against the insults of a Spanish expat (Reyes Gavilán 1951:71). In that same year, he published a short biography of the Maceo family, which laid out its patriotic credentials and his claim to them. Gregorio also contacted Maceo's immediate relatives in Cuba, though only two of them-Antonio's elderly sister Dominga and her son, Marcos—would recognize him (Cremata Ferrán 2005). But the cornerstone of Bustamante's case was a series of legal documents, certified by a Honduran court, attesting to the authenticity of his heritage (Bustamante 1938). He disseminated his text widely throughout Cuba, culminating in an invitation to travel there in December 1938. But this trip never came to fruition. Cuban President Laredo Brú refused to cover his travel, and Bustamante alleged that high-placed enemies in Honduras and Cuba, including Antonio Maceo Maryatt, were responsible for that decision (Souza 1951:39-40; Reyes Gavilán 1951). Nonetheless, he would not be discouraged.

In 1951, thanks to the initiative of several Cuban reporters, Gregorio finally received the invitation he had awaited and undertook his triumphant journey to Cuba. There, he was greeted with popular acclaim. The presence of the hero's son had, according to one journalist, "lit up ... the hearts of the Cuban masses," who closely followed him in his tour through Havana, accompanied by Marcos Romero Maceo (Reyes Gavilán 1951:52). Observers made much of Gregorio's love for Cuban coffee and tobacco and his military distinctions. Cuban Cardinal Manuel Arteaga y Betancourt even declared him to be the spitting image of his father (Cremata Ferrán 2005; Reyes Gavilán 1951:71).

Like their lay counterparts, Cuban historians would also participate in assessing Bustamante's claims to Maceo's heritage. Leading the pack was José Luciano Franco (1891-1989), still considered one of Cuba's most distinguished historians. At a time when many of his colleagues responded to the disappointments of Republican life by grounding their scholarship in Marxist and anti-imperialist thought, Franco was unique in foregrounding the formative influence of slavery and racism in Cuban history (Fagen 1976). His multivol- 
ume biography of Antonio Maceo, the product of archival research in the many places where his subject had been exiled, helped to inform a renewed historical consensus on Maceo, in which he represented a potent lesson on "what might have been but had gone wrong" for Cuba (Fagen 1976:75).

The direct interaction between Cuban historians and this human challenger was undoubtedly unique. Even so, the reaction to Bustamante's pretensions sheds light on an enduring problematic in Cuban historiography. The scholars who came of age in the 1940s and 1950s are often celebrated for their empirically grounded work, which challenged the colonial politics of previous schools. The "revisionists," as they are often called, rooted their research in an anti-imperialist ethos; as Kate Quinn argues, "Cuban revisionism" is thus largely "synonymous with Cuban nationalism" (Quinn 2007:380). Many classic texts would both anticipate and ground political transformations to come (Iglesias García 1999). Nonetheless, in claiming Maceo as an avatar of the Cuban nation, professional historians, like others before them, would have to contend with the insinuations of apocryphal sons. They would engage them most directly as a historical problem but also, implicitly, as a moral one.

When Gregorio arrived in Cuba in 1951, Franco's research had prepared him to engage with Bustamante's assertions. By 1951, these included several new details. Maceo, Gregorio explained in a press conference, had been sent to Honduras as part of a secret commission in 1870 . It was during that trip that Maceo had met his mother, Pastora Bustamante, leading to the conception and birth of Gregorio (Franco 1951). Bustamante insisted that his grandparents, "Spaniards of an ancient line," had subsequently forced his mother to renounce Maceo, whom she "worshipped," because he was black (Delgado Fernández 1951:24; Reyes Gavilán 1951:71). As Franco would point out, however, three basic facts, however, stood in the way of Bustamante's assertions. First, there had been no special Cuban commission to Honduras in 1870. Second, Antonio Maceo did not depart Cuban soil for the first time until 1878. Third, he did not arrive to Honduras until 1881, and did not meet Pastora Bustamante until 1882 (Franco 1951). By this time, Gregorio Bustamante was already ten years old. Bustamante's birth certificate, acquired for the first time as a result of the controversy, plainly listed January 21, 1872 as his birthdate (Delgado Fernández 1951:20).

On the basis of these incongruities, Franco and other experts, who had been summoned by Havana's new Academy of History to assess Gregorio's story, quickly ruled against him. Antonio Maceo, their final report maintained, had only one son: Antonio Maceo Maryatt. Prior to their ruling, a group of historians from Santiago de Cuba also weighed in, voicing the same skepticism about Bustamante while acknowledging that they could not be sure that Maceo Maryatt 
was Maceo's only son. ${ }^{83}$ After all, Franco himself seems to have acknowledged that Pastora Bustamante and Antonio Maceo had an amorous relationship or, at the very least, that Pastora's husband was jealous of her affection for Maceo (Franco 1951:28-29). It was widely known that Maceo had at least one lover in Honduras, and a comrade had once written to warn him of the impending visit of his wife (Franco 1951:28).

Though commentators on the Bustamante controversy were generally loath to indulge in speculations about Maceo's personal life, they could not completely disavow the possibility of unknown sons. As one participant in the deliberations conceded, most of Cuba's "liberators, who lived a nomadic life, at some point over the years, separated from their homes, were forced to fall in indiscretions." This, he acknowledged, had rendered "Spanish America ... a gold mine, propitious grounds for those seeking to exploit certain fictions." Among all the liberators, he added, none had been more "favored with apocryphal sons than our great caudillo, lieutenant Antonio Maceo" (Cremata Ferrán 2005; Souza 1951:28).

Over a century ago, Thomas Carlyle, one of the most famous practitioners of great man history, insisted on its moral and political value: "Universal History, the history of what man has accomplished in this world, is at bottom the History of the Great Men who have worked here ... We cannot look, however imperfectly, upon a great man, without gaining something by him" (Carlyle 1842:6). In contrast, professional historians today often disown the "great man" style of history altogether. For generations, members of the guild have instead sought to rescue the experiences of ordinary people, to reach beyond the pantheons around which "romantic histories" were often written.

After 1959, social history would also find a propitious seat in Cuba, where a pioneering generation of revolutionary historians, many drawing on the example of the revisionists, would seek to chronicle the history of "people without history," per the classic formulation of Juan Pérez de la Riva. In some cases, notably that of José Luciano Franco, the revisionists and the revolutionaries were one and the same. They did not, however, always repudiate the great men of the past. Histories of slavery, the working class, and Cuba's indigenous popu-

83 Both reports are reprinted in Nuevas pruebas sobre la descendencia de Antonio Maceo, pp. 47-51 and 51-55, respectively. See also Cremata Ferrán 2005. 
lation were constructed in productive tension with a tenacious hagiographical strand, centered on the island's nationalist pantheon.

For generations of Cubans, Antonio Maceo has represented one such "great man," periodically rediscovered so that the nation might gain something by him. But historiographical celebration was sometimes incommensurate with the complexities of the island's past, particularly as they manifested in the area of race. Franco and others sought to practice a respectfully distanced gaze on their icon. Yet the problem of apocryphal sons returned attention to the terrain of Maceo's terrestrial-indeed, embodied - existence. This was an unacceptably imperfect kind of looking.

Since his earliest years in the independence struggle, Maceo had been forced to contend with discrimination on the basis of his blackness. In this, the hero's corporeality always stood in the way. Yet Maceo's body was also long cast as the source of his special power, the physical motor of the struggle for sovereignty. Throughout Maceo's life and for decades following his death, commentators marveled over the "size, strength and invulnerability of his body," a powerful metaphor for the independence cause (Nathan 2007:11). So complete was this identification between Maceo's body and the viability of the revolutionary struggle that Cubans reacted to the news of his death with disbelief and despair. ${ }^{84}$

The association of Maceo with brawn-and José Martí with intellectclearly adhered to racist scripts of the late nineteenth and early-twentieth centuries. ${ }^{85}$ Even so, it was not an altogether uncomplicated association. Racial prejudice led admirers to focus on Maceo's strength over other attributes, but it also rendered his physicality a potentially threatening object. Public depictions of Maceo's body therefore endowed it with platonic, even otherworldly, qualities, as in the frequent attention to Maceo's 26 bullet wounds, which he was wont to display. In a prominent motif of the independence battles, Maceo's death alongside his white aide, son of the leader Máximo Gómez, offered an "iconic" vision of "racial unity" in the intermingling of their blood (Ferrer 1999:121; Nathan 2007:26). The desire to purge Maceo's body of the racial threat embodied therein is perhaps most dramatically encapsulated in the postmortem determination of three Cuban scientists that his remains "revealed a fortuitous racial mixture of a 'white' brain capacity blended with 'black' limb proportions" (Bronfman 2004:1). ${ }^{86}$

84 For weeks, the Cuban and U.S. press reported uncertainty about whether Maceo had actually perished or whether it was a Spanish ruse to leave the Cuban forces dispirited.

85 See de la Fuente 2001, Guerra 2005, Guridy 2010, Helg 1995, and Luis-Brown 2010.

86 A more unusual, but no less suggestive, eugenic judgment was rendered by Maceo's 
The dual charge of Maceo's body-incorporeally iconic but inescapably black—rendered attention to his sexual life and offspring all the more sensitive. Little surprise, then, that the posthumous construction of Maceo as nationalist totem largely bracketed the racial prejudice that had plagued him in his lifetime and its consequences as reflected in the cult to his strength. On the one hand, this spoke to a desire to protect patriotic icons from the inevitable disappointments attached to their humanity. Insinuations of extramarital liaisons were unsurprising, given the conditions of exile and war, if unwelcome. But the special scrutiny attached to Maceo's false children seems to point to something else entirely: a compulsion to revisit, however unconsciously, the racial ambivalence that had rendered his body at once iconic and taboo.

Gregorio Bustamante may have been the last gasp of Maceo's filial phantasmagoria. He was not, however, the final Maceo. Cosmopolitan affinities would inspire more than a few African Americans to claim "Maceo" or even "Antonio Maceo" as a name for their children. ${ }^{87}$ From Antonio Maceo Cosey, a celebrated jazz musician, and Maceo Parker, a celebrated funk saxophonist, to A. Maceo Walker, a community leader and civil rights activist, the tradition stretches all the way to Maceo Cleaver, son of Eldridge and Kathleen Cleaver, two of the most famous leaders of the Black Panthers.

It is not hard to understand why these symbolic lineages have offered such a powerful vehicle of identification. This was the very spirit in which Maceo's partisans, along with Cuban politicians and intellectuals, sought to stabilize the content of his biography: to put his life and his death to the service of nationalist goals. Stories about long-lost or "illegitimate" sons were in this regard anathema to lionization, at best a pesky distraction and at worst an intolerable assault on a patriot's honor. Yet Santiago, Daniel, Gregorio, and others were also motivated by Maceo's very greatness, and the opportunity to bask in his eminence by proxy. Their claims on his descent did not entitle them to a crown or riches - at best, a modest state pension — but the name itself was a weighty inheritance, sanctifying past struggle and portending future glory.

Even so, narratives of apocryphal sons could also produce contrary symbolic effects. Speculation about hidden and unknown offspring allowed Cubans (and Americans) to reimagine Maceo — and by extension the nation at largeunbeholden to actual historical outcomes. At the most basic level, such discussions revivified and newly humanized an increasingly distant icon, as in the

close friend and pioneering Cuban homiculturalist, Eusebio Hernández (1968:165), who referred to Maceo as the "arm of the Revolution, but an arm propelled by his own calculation [pensamiento]."

87 On a similar phenomenon with respect to Simón Bolívar, see Fitz 2016. 
acclaimed visit of Gregorio Bustamante to Havana. Sometimes, this also served to reinvigorate the nationalist imaginary, grounded in the porous body of one of its most acclaimed avatars. Just as often, however, the stories of false and real sons served to highlight what had been forgotten or, more often, silenced in the transition to independence, including the project of antiracism itself.

Invariably, then, in these choose-your-own-adventure paths through alternative futures, race and empire recur: the submerged but inescapable subtext of the independence epic. In this way, tales of false sons were not so distant from the efforts of Franco and his generation of historians to recast Maceo's biography in the service of political critique and validate their disillusionment with the state that succeeded independence. Both tasks, however, required participants to linger in body politics in ways that could prove disruptive to grand narratives and uncomplicated heroes. Here, we find the unsettling stutter of filial phantasmagoria: neither redemptive nor transcendent, but finally and unrepentantly weird.

\section{Acknowledgments}

I would like to thank friends and colleagues who have offered feedback on this work, especially Michael Bustamante, Anne Eller, Debbie Weinstein, Debby Levine, Lillian Guerra, Guadalupe García, Elizabeth Mirabal, Alejandro Vázquez, and three anonymous readers for New West Indian Guide. I am particularly grateful to Marial Iglesias Utset for sharing her own sources and reflections about Antonio Maceo Maryatt, and to Jonathan Deiss who heroically pieced together the fragments of Santiago Maceo's U.S. military career. I am also indebted to the work of those writers and historians, especially Damaris Torres Eler and Mario Cremata Ferrán, who have brought new attention to Maceo's real and fictive offspring.

\section{References}

Álvarez Pitaluga, Antonio, 2008. La familia de Máximo Gómez. Havana: Editora Política. Barcia, María Del Carmen, Jorge Ibarra Cuesta, Yahima Leyva Collazo \& Fernando Carr Parúas, 2009. Mujeres almargen de la historia. Havana:Editorial de Ciencias Sociales.

Barcia Zequeira, María Del Carmen, 2010. La otra familia: Parientes, redes y descendencia de los esclavos en Cuba. Havana: Editorial Oriente, Instituto Cubano del Libro.

Bronfman, Alejandra, 2004. Measures of Equality: Social Science, Citizenship, and Race in Cuba, 1902-1940. Chapel Hill: University of North Carolina Press. 
Bustamente, Gregorio, 1938. Biografía de los Maceo (Héroes Cubanos). San Salvador, El Salvador: Imprenta G.A. Funes.

Butler, Judith, 2015. Senses of the Subject. New York: Fordham University Press.

Carlyle, Thomas, 1842. On Heroes, Hero-Worship, and the Heroic in History: Six Lectures. Cincinnati OH: U.P. James. [Orig. 1841.]

Cepero Bonilla, Raúl, 1948. Azúcary abolición, apuntes para una historia crítica del abolicionismo. Havana: Editorial Cenit.

Chambers, Sarah C., 2015. Families in War and Peace: Chile from Colony to Nation. Durham NC: Duke University Press.

Cowling, Camillia, 2013. Conceiving Freedom: Women of Color, Gender, and the Abolition of Slavery in Havana and Rio de Janeiro. Chapel Hill: University of North Carolina Press.

Cremata Ferrán, Mario, 2005. El hijo de Antonio Maceo. Opus Habana 9(2). http://www .opushabana.cu/index.php/articulos/36-articulos-casa-de-papel/572-el-hijo-deantonio-maceo.

Cupull, Adys \& Froilán González, 1998. Mariana:Raíz del alma cubana. Havana: Editora Política.

Davis, Natalie Zemon, 2007. The Return of Martin Guerre. Cambridge MA: Harvard University Press.

Davis, Natalie Zemon, 2013. Trickster Travels: A Sixteenth-Century Muslim between Worlds. New York: Farrar, Straus \& Giroux.

Dela Fuente, Alejandro, 1999. Myths of Racial Democracy: Cuba, 1900-1912. Latin American Research Review 34(3):39-73.

De la Fuente, Alejandro, 2001. A Nation for All: Race, Inequality, and Politics in Twentieth-Century Cuba. Chapel Hill: University of North Carolina Press.

Delgado Fernández, Gregorio, 1951. Es falso, de toda falsedad, que el hondureño don Gregorio Bustamante, sea hijo de Antonio Maceo. In Nuevas pruebas históricas sobre la descendencia de Antonio Maceo. Havana: Municipio de la Habana, pp. 931. [Cuadernos de Historia Habanera No. 50.]

Díaz Martínez, Yolanda, 2005. La peligrosa Habana: Violencia y criminalidad a finales del siglo XIX. Havana: Editorial de Ciencias Sociales.

Edelman, Lee, 1998. The Future Is Kid Stuff: Queer Theory, Disidentification, and the Death Drive. Narrative 6(1):18-30.

Escalona Chádez, Israel \& Damaris A. Torres Elers (eds.), 2016. Dos titanes en la historia y la cultura cubanas. Santiago, Cuba: Ediciones Santiago.

Fagen, Patricia Weiss, 1976. Antonio Maceo: Heroes, History, and Historiography. Latin American Research Review 11(3):69-93.

Fanon, Frantz, 2011. The Wretched of the Earth. New York: Grove Press. [Orig. 1961; orig. English translation 1963.]

Fanon, Frantz, 2017. Black Skin, White Masks. London: Pluto Press. [Orig. 1952; orig. English translation 1967.] 
Fernández, Damian J., 2010. Cuba and the Politics of Passion. Austin: University of Texas Press.

Ferrer, Ada, 1999. Insurgent Cuba: Race, Nation, and Revolution, 1868-1898. Chapel Hill: University of North Carolina Press.

Findlay, Eileen, 2014. We Are Left Without a Father Here: Masculinity, Domesticity, and Migration in Postwar Puerto Rico. Durham NC: Duke University Press.

Fitz, Caitlin, 2016. Our Sister Republics: The United States in an Age of American Revolutions. New York: Liveright.

Flake, Dennis Edward, 2009. Loyal Macabebes: How the Americans Used the Macabebe Scouts in the Annexation of the Philippines. Angeles City, Philippines: Juan D. Nepomuceno Center for Kapampangan Studies, Holy Angel University.

Fowler Calzada, Víctor, 2013. Paseos corporales y de escritura. Havana: Letras $\mathrm{Cu}-$ banas.

Franco, José Luciano, 1951. La verdad histórica sobre la descendencia de Antonio Maceo. Havana: Municipio de la Habana. [Cuadernos de Historia Habanera No. 47.]

Franklin, Sarah L., 2012. Women and Slavery in Nineteenth-Century Colonial Cuba. Rochester NY: University of Rochester Press.

Gatewood, Jr., Willard B., 1999. “Smoked Yankees” and the Struggle for Empire: Letters from Negro Soldiers, 1898-1902. Fayetteville: University of Arkansas Press.

Gilroy, Paul, 2010. Postcolonial Melancholia. New York: Columbia University Press.

Greenbaum, Susan D., 2002. More Than Black: Afro-Cubans in Tampa. Gainesville: University Press of Florida.

Greenwalt, Emmett A., 1955. The Point Loma Community in California 1897-1942: A Theosophical Experiment. Berkeley: University of California Press.

Grillo, Evelio, 20oo. Black Cuban, Black American: A Memoir. Houston: Arte Público Press.

Guerra, Lillian, 2005. The Myth ofJosé Martí: Conflicting Nationalisms in Early TwentiethCentury Cuba. Chapel Hill: University of North Carolina Press.

Guridy, Frank Andre, 2010. Forging Diaspora: Afro-Cubans and African Americans in a World of Empire and Jim Crow. Chapel Hill: University of North Carolina Press.

Helg, Aline, 1995. Our Rightful Share: The Afro-Cuban Struggle for Equality, 1886-1912. Chapel Hill: University of North Carolina Press.

Helg, Aline, 1997. Race and Black Mobilization in Colonial and Early Independent Cuba: A Comparative Perspective. Ethnohistory 44(1):53-74.

Hernández, Eusebio, 1968. Maceo: Dos conferencias históricas. Havana: Instituto del Libro.

Herzog, James M., 2014. Father Hunger: Explorations with Adults and Children. New York: Routledge.

Hevia Lanier, Oilda \& Daisy Rubiera Castillo (eds.), 2016. Emergiendo del silencio: Mujeres negras en la historia de Cuba. Havana: Editorial de Ciencias Sociales. 
Hobbs, Allyson Vanessa, 2016. A Chosen Exile: A History of Racial Passing in American Life. Cambridge MA: Harvard University Press.

Hoganson, Kristin L., 1998. Fighting for American Manhood: How Gender Politics Provoked the Spanish-American and Philippine-American Wars. New Haven CT:Yale University Press.

Hunt, Lynn, 2013. The Family Romance of the French Revolution. London: Routledge.

Iglesias García, Fe, 1999. Historiography of Cuba. In B.W. Higman (ed.), General History of the Caribbean: Methodology and Historiography of the Caribbean. Vol. 6. London: UNESCO, pp. 343-87.

Jacoby, Karl, 2016. The Strange Career of William Ellis: The Texas Slave Who Became a Mexican Millionaire. New York: W.W. Norton \& Co.

Jarvinen, Lisa, 2012. Educating the Sons of the Revolution: The Cuban Educational Association, 1898-1901. In Richard Garlitz \& Lisa Jarvinen (eds.), Teaching America to the World \& the World to America: Education and Foreign Relations since 1870. New York: Palgrave Macmillan, pp. 73-91.

Jimoh, A. Yemisi \& Françoise N. Hamlin, 2015. These Truly Are the Brave: An Anthology of African American Writings on War and Citizenship. Gainesville: University Press of Florida.

Kramer, Paul A., 2006. The Blood of Government: Race, Empire, the United States, and the Philippines. Chapel Hill: University of North Carolina Press.

Krauel, Javier, 2012. Ángel Ganivet's Idearium español as Fin-de-Siècle Imperial Melancholia. Revista Hispánica Moderna 65(2):181-97.

Lane, Jill, 2010. Smoking Habaneras, or a Cuban Struggle with Racial Demons. Social Text 104:11-37.

Lee, Fred, 2013. Reconsidering the Jefferson-Hemings Relationship: Nationalist Historiography Without Nationalist Heroes, Racial Sexuality Without Racial Significance. Political Research Quarterly 66(3):500-15.

Lucero, Bonnie A., 2015. Civilization Before Citizenship: Education, Racial Order, and the Material Culture of Female Domesticity in American-Occupied Cuba (18991902). Atlantic Studies 12(1):26-49.

Lucero, Bonnie A., 2018. Revolutionary Masculinity and Racial Inequality: Gendering War and Politics in Cuba. Albuquerque: University of New Mexico Press.

Luis-Brown, David, 2010. Waves of Decolonization: Discourses of Race and Hemispheric Citizenship in Cuba, Mexico, and the United States. Durham NC: Duke University Press.

Martinez-Alier, Verena, 1974. Marriage, Class and Colour in Nineteenth-Century Cuba: A Study of Racial Attitudes and Sexual Values in a Slave Society. Cambridge: Cambridge University Press.

Mcclintock, Anne, 1995. Imperial Leather: Race, Gender, and Sexuality in the Colonial Conquest. New York: Routledge. 
Milanich, Nara B., 2009. Children of Fate: Childhood, Class, and the State in Chile, 18501930. Durham NC: Duke University Press.

Mirabal, Elizabeth, 2013. La intimidad de la historia. Havana: Ediciones ICAIC, Fundación Alejo Carpentier.

Mitscherlich, Alexander \& Margarete Mitscherlich, 1991. The Inability to Mourn: Principles of Collective Behavior. New York: Grove Press.

Morrison, Karen Y., 2015. Cuba's Racial Crucible: The Sexual Economy of Social Identities, 1750-2000. Bloomington: Indiana University Press.

Murat, Laure, 2014. The Man Who Thought He Was Napoleon: Toward a Political History of Madness. Chicago: University of Chicago Press.

Nathan, Robert C., 2007. Imagining Antonio Maceo: Memory, Mythology and Nation in Cuba, 1896-1959. MA thesis, University of North Carolina at Chapel Hill.

Paddison, Joshua, 2012. American Heathens: Religion, Race, and Reconstruction in California. Berkeley: University of California Press.

Pappademos, Melina, 2014. Black Political Activism and the Cuban Republic. Chapel Hill: University of North Carolina Press.

Pérez, Jr., Louis A., 1999. On Becoming Cuban: Identity, Nationality and Culture. Chapel Hill: University of North Carolina Press.

Pérez, Jr., Louis A., 2005. To Die in Cuba: Suicide and Society. Chapel Hill: University of North Carolina Press.

Pérez, Jr., Louis A., 2008. Cuba in the American Imagination: Metaphor and the Imperial Ethos. Chapel Hill: University of North Carolina Press.

Portuondo Linares, Serafin, 1950. Los independientes de color: Historia del Partido Independiente de Color. Havana: Editorial Libr. Selecta.

Prados-Torreira, Teresa, 2005. Mambisas: Rebel Women in Nineteenth-Century Cuba. Gainesville: University Press of Florida.

Putnam, Lara, 2013. Radical Moves: Caribbean Migrants and the Politics of Race in the Jazz Age. Chapel Hill: University of North Carolina Press.

Quinn, Kate, 2007. Cuban Historiography in the 1960s: Revisionists, Revolutionaries and the Nationalist Past. Bulletin of Latin American Research 26(3):378-98.

Reyes Gavilán, Antonio, 1951. Visita la Habana el hijo de Antonio Maceo. Bohemia $43(22): 52-54,71$.

Rodríguez Sarabia, Aída, 1957. Mariana Grajales, madre de la patria. Havana: n.p.

Roig De Leuchsenring, Emilio, 1945. Ideología político-revolucionaria. In La vida heroica de Antonio Maceo. Havana: Municipio de la Habana [Colección Histórica Cubana y Americana.]

Roig De Leuchsenring, Emilio, 1951. Nota preliminar. In Nuevas pruebas sobre la descendencia de Antonio Maceo. Havana: Municipio de la Habana, pp. 7-9. [Cuadernos de Historia Habanera No. 5o.]

Rubiera Castillo, Daisy \& Maria Inés Martiatu Terry (comp.), 2011. Afrocubanas: Historia, pensamiento y prácticas culturales. Havana: Editorial de Ciencias Sociales. 
Sarabia, Nydia, 1976. María Cabrales. Havana: Editorial Gente Nueva, Instituto Cubano del Libro.

Sarabia, Nydia, 2006. Historia de una familia mambisa: Mariana Grajales. Havana: Editorial de Ciencias Sociales.

Scott, Rebecca J., 1985. Slave Emancipation in Cuba: The Transition to Free Labor, 18601899. Pittsburgh PA: University of Pittsburgh Press.

Sierra Madero, Abel, 2006. Del otro lado del espejo: La sexualidad en la construcción de la nación cubana. Havana: Fondo Editorial Casa de las Américas.

Smith, Stacey L., 2015. Freedom's Frontier: California and the Struggle over Unfree Labor, Emancipation, and Reconstruction. Chapel Hill: University of North Carolina Press.

Sommer, Doris, 2007. Foundational Fictions: The National Romances of Latin America. Berkeley: University of California Press.

Sosa Borjas, Zoe, 2015. Antonio Maceo en la historiografía cubana: El tratamiento a aspectos controvertidos de su biografía. Santiago, Cuba: Editorial del Caribe.

Souza, Benigno, 1951. Los falsos delfines: El coronel Gregorio Bustamante. In Nuevas pruebas históricas sobre la descendencia de Antonio Maceo. Havana: Municipio de la Habana, pp. 31-47. [Cuadernos de Historia Habanera No. 5o.]

Stoker, Bram, 1910. Famous Imposters. New York: Sturgis \& Walton.

Stoler, Ann Laura (ed.), 2007. Haunted by Empire: Geographies of Intimacy in North American History. Durham NC: Duke University Press.

Stoler, Ann Laura, 2010. Carnal Knowledge and Imperial Power: Race and the Intimate in Colonial Rule. Berkeley: University of California Press.

Stoner, K. Lynn, 2003. Militant Heroines and the Consecration of the Patriarchal State: The Glorification of Loyalty, Combat, and National Suicide in the Making of Cuban National Identity. Cuban Studies 34(1):71-96.

Torres Elers, Damaris A., 2006. Antonio Maceo Maryatt: El hijo del titán de Bronce. In Centro de Estudios Antonio Maceo. Santiago, Cuba: Ediciones Santiago.

Torres Elers, Damaris A., 2013. María Cabrales: Una mujer con historia propia. Santiago, Cuba: Editorial Oriente.

Torres Elers, Damaris A. \& Israel Escalona Chádez, 2015. Mariana Grajales Cuello: Doscientos años en la historia y la memoria. Santiago, Cuba: Ediciones Santiago.

Valdés, Nelson, 1992. Cuban Political Culture: Between Death and Betrayal. In Sandor Halebsky et al. (eds.), Cuba in Transition: Crisis and Transformation. Boulder CO: Westview Press, pp. 207-28.

Vasconcellos, Colleen A., 2015. Slavery, Childhood, and Abolition in Jamaica, 1788-1838. Athens: University of Georgia Press.

Žižek, Slavoj, 20oo. Melancholy and the Act. Critical Inquiry 26(4):657-81. 